\title{
The Information Literacy of Teachers and Students in Information Era
}

\author{
Li Cuibai \\ College of Elementary Education \\ Hainan Normal University \\ Haikou, Hainan, China \\ 405900956@qq.com
}

\begin{abstract}
In order to discussing the information literacy requirement of the teachers and students in information era, The paper first elaborates the connotation of concept and basic elements of information literacy, analyzes the information-based teaching skill of teachers should possess in the information education, thus puts forward the significance of the development of the standards of education technology ability for teachers, and expounds the connotation of the standard which help to improve the Information Literacy of teachers and students.
\end{abstract}

Keywords- Information Education; Information Literacy; teachers; students; standard of education technology

\section{INTRODUCTION}

At present, all over the world the information literacy is as the core elements of quality education in curriculum and teaching reform. It reflects the requirements of information age, reflects the modern characteristics of education, is the inherent demand for the development of education information. This article explores the connotation of concept of information literacy, and then analysis of the information literacy for middle school students and teachers, and thus elaborate teachers education technology ability standard and its significance.

\section{THE CONNOTATION OF CONCEPT OF INFORMATION LITERACY}

\section{A.The Concept of Information Literacy}

The 21 st century is the era of information education, "Information Literacy" is given to specific requirements of educators and learners in the modern information society .Information Literacy is the extension and expansion of the traditional culture accomplishment, is also constitute the foundation of the lifelong education system. Information Literacy not only includes the use of information tools and the ability of information resources, also includes selecting identification information, processing, transfer information and the ability to create information. Tracing the concept of "information literacy", in 1989, the American Library Association (American Library Association, ALA) defines it as follows: Information Literacy is to determine when to need information, and know how to get information, how to evaluate and effective use of the information required. In 2001, the American Education Technology CEO BBS fourth quarter report puts forward the abilities of the 21st century, including the basic learning skills (read, write, calculate), information literacy and innovation thinking ability, interpersonal communication and cooperation spirit and practice ability. At present about Information literacy has not been unified definition, but it is generally believed that Information Literacy contains three basic points: (1) the application of information technology skills. This point refers to the use of information technology in information acquisition, processing and communication skills. It is through the study of the information technology skills of learners and application practice training to develop. (2) the ability of criticism and understanding for information content. At all stages of information collection, processing and utilization, critically process information is an important characteristic of information literacy and information retrieval strategy, by using of the information source, the information content can be individually assessed, think seriously about the validity of the information, the accuracy of information presentation, the logical contradiction or identifying information reasoning fallacy, the recognition information according to or no according to judgment, to determine the adequacy of the argument. The formation of the literacy is not only formed through training of computer technology skills, but rather by strengthening scientific analysis thinking ability training to develop.(3) the use of information which attitude and ability has integrated into the information society. This refers to the information users want to have strong social sense of responsibility, has the good cooperation with others working spirit, make the application of information technology to promote social progress, and make a contribution to society.

\section{B.Information Literacy for Students in Middle School} should have in Information Education

Students' information literacy is according to the requirement of the development of social information environment and information, in the process of school education and self-improvement the attitude of the form of information activities, and the use of information and information method to solve the problems. Information literacy is mainly has five characteristics: capture information decisiveness of sharpness, screening information, the accuracy of evaluation information, exchange information freely and application information 
of the original. It should include the student understanding of information basic knowledge, mastery, and the methods of information tools to use in the future study of information and knowledge in the teaching, should also include the understanding of information ethics and abide by it. Specifically, it mainly includes four aspects:(1) information consciousness. The sensitivity of information, is various phenomena of nature and society, behavior, and theoretical perspectives, understanding, feeling and evaluation from the Angle of information. Informally, facing the things they don't understand, can actively searching for answers, and know where, with what method to seek the answer, this is the information consciousness. Information age everywhere contains all kinds of information, can be very good use of existing information, is the important embodiment of strong information consciousness is not strong. Using information technology to solve the problems of the work and life consciousness, this is the most important point in information technology education.(2) information knowledge. Both the theoretical basis of science and technology, information and learning the basic requirements of information technology. By mastering the knowledge of information technology, to better understand and apply it. It not only embodies the student has abundance of information and knowledge, but also restricts the further grasp of information and knowledge. (3) the information ability. Including the operation ability of the information system, information collection, transmission, processing and application of ability, and ability to evaluate the information system and information, etc. It is also important in the information age survival ability. In the information age if only has a strong sense of information and abundant information, common sense and do not have a high information ability, still can't effectively using a variety of information tools to deal with the collection, acquisition, transmission, processing, valuable information, not improve the learning efficiency and quality. The information ability is the core of the essential elements of information literacy, students must have strong ability of information, otherwise difficult to survive and develop in the information society.(4) information ethics. Trains the student to have the correct information ethics accomplishment, let the students learn to judgment and choice of media information, consciously choose to study, the content of the useful life, consciously resist the unhealthy content, organization and not engage in illegal activities, not using the computer network information system and network security to endanger others, infringing on lawful rights and interests of others. This is also an important embodiment of information literacy.

The four elements of Information literacy constitute one indivisible unified whole. Information consciousness is the forerunner, information is the foundation of knowledge, information ability is the core, then moral is to ensure that information.

\section{THE INFORMATION TEACHING SKILLS OF TEACHERS IN THE INFORMATION EDUCATION.}

Information technology brought great changes to our education, in order to adapt to the change of modern information technology brings to the teaching, teachers have to change, improve the information literacy of the self. In the information-based education teachers should become the guide of students to learn and the promoters of learning construction. The development of modern education technology has changed the traditional instructional method of teachers for students to have the status of the absolute authority, compared with the students, teachers must keep on learning new knowledge, new theory, especially in learning new education psychology theory, learning theory, and exploring new teaching rule, method.It takes more time and energy. Combining with the current information technology and curriculum integration, in the information technology under the network environment, the teacher should develop the information teaching skills and have the following ability:(1)To have a basic understanding of the computer and its peripheral equipment, run into simple machine failure to eliminate.(2) Proficient in the Internet, know certain knowledge of network connection. As the campus local area network (LAN) access to the Internet, mobile Internet network environment; Dial-up, ADSL Internet access in the home environment. So that we can to meet a simple network fault, relying on their own knowledge, rule out the failure of simple.(3) Can skilled in the Internet browsing, skillfully use all kinds of search engines and reasonable use of search strategy to obtain the information you need on the Internet.(4) Master office application software: the WORD (WORD processing), EXCEL (spreadsheet), POWERPOINT slides (electronic) operation of office automation software; software of picture such as ACDsee; Winamp sound playback software; Video player software super XieBa and Jin Shanying bullies.5. Master the commonly used multimedia production software. As the need of further, commonly used multimedia production software is also very important, such as professional production often use Authorware multimedia (interactive multimedia courseware), Flash (animation), Photoshop (image processing), Frontpage or Dreamweaver (web design), Premiere (video editor), Sound forge (Sound editor), and so on. 6. Proficient in application of network tools to carry out the teaching. Teachers commonly used network communication tools including Email, BBS, QQ, WeChat and various social networking platform, etc. In addition, the education network applications, blogs, social software and a variety of network learning platform (such as Blackboard, longed for platform, etc.) is becoming new tool in instruction and research of network information platform.

\section{STANDARD OF ABILITY OF EDUCATION TECHNOLOGY FOR TEACHERS.}

In order to improving teachers' information literacy, promote the information teaching training content and method reform, countries around the world have 
formulated and issued the relevant education laws and regulations and guidance documents.In order to make clear the standard of teacher education technique ability, standards of teachers' education technology is proposed.(1) The standard of teacher education technique ability in our country to improve primary and secondary school teachers education technology ability level. In December of 2004, China's ministry of education formally promulgated the primary and secondary school teachers education technology ability standard (try out) ".It is China's first formulated by the education technology professional ability standard, for the training of primary and secondary school teachers' information literacy has important guiding significance. Standard applicable to the primary and secondary school teaching staff, management of primary and secondary schools, primary and secondary schools, technical support personnel education technical ability training and assessment. In the ability of teaching staff in the standard, the standard rules for primary and secondary school teachers should possess from four aspects of education technique ability quality: consciousness and attitude (including the understanding of the importance and application consciousness, evaluation and reflection, lifelong learning, etc.);Knowledge and skills, including basic knowledge, basic skills, etc.);Application and innovation (including the design and implementation, teaching support and teaching management, scientific research and development, cooperation and communication, etc.);Social responsibility, including fair use, standardize behavior, effective application, health, etc.).Application and innovation of the third level "" refers to how to the level of technology and innovation in teaching, it directly reflects the ultimate goal of cultivating the ability of teachers' information technology teaching, has been clear about the China's primary and secondary school teachers education technology ability standard should be to design and implementation of teaching, teachers' use of technology and provide technical support for the students of teaching resources development and management service as the core.(2)The technical standards of teachers' education in the United States. The United States is one of the first countries to make teacher education technology standard, the United States education technology association has successively formulated the "standard of American education technology for teachers" (2000, 2008), "for students of American education technology standard" (1998), 2007 edition).Among them, the teachers' education technology oriented standard proposed the teacher should reach the standard of education technology, i.e., the technology of operation and concepts, planning and design of learning environment and experience, and technology related teaching, learning and curriculum, assessment and evaluation, work efficiency and the social, ethical, legal and professional practice, human issues.(3) Standard of teachers' ability of information and communication technology. The United Nations educational, scientific and cultural organization in January 2008 issued a "standard of teachers' ability of information and communication technology" (hereinafter referred to as the "standard"), purpose is to help determine the technical skills required for teachers in the education work. Standard through and dissemination of the information technology and teaching methods, curriculum and school organization the new viewpoint, the combination of promoting teachers' professional development, advocate the teachers will use various skills in information and communication technologies and resources to improve the teaching quality, promote students' learning, cooperation with colleagues, and may eventually become education institutions to carry out the information teaching innovator and leader. The techniques of teachers as the standard is education innovator and leader of the meaning.

\section{CONCLUSIONS}

In the information era, most schools are equipped with computer hardware, it is not only to ensure that teachers can effectively use information technology to teaching, in addition to the teachers must be familiar with the information and communication technology, should also master the information instructional design, learning resource development and management services and other aspects of information technology teaching ability. The teacher must keep learning in the information era. And the modern education technology is related to new ideas, new knowledge, new skills. Teachers should learn to incorporate new technology in teaching, use the new method to promote the teaching reform, improve their information-based teaching ability.

\section{ACKNOWLEDGMENT}

I would like to express my gratitude to all those who have helped me during the writing of this thesis.I gratefully acknowledge the help of the editior who have paied so much attention on reading this paper.

The work of this paper is supported by 2010 Humanities and Social Science Foundation of Ministry of Education of China (Grant No. 10YJC880063) and 2015 Instructional Reform Project of Higher Education Foundation of Hainan Educational Committee (Grant No. Hnjg2015ZD -7).

\section{REFERENCES}

[1] Shao-qing Guo, Wang Weijun editor. The teacher information technology ability tutorial $[\mathrm{M}]$. Beijing: higher education press, 2010.7.

[2] Li Cuibai,"Information technology and curriculum integration, the modern education technology training tutorial,"Beijing:Science Press, 2014.8.

[3] Jian-ping Zhang. The modern education technology (3rd edition). Beijing: higher education press, 2013.03.

[4] Ming-jian Fang compiled. Based on the problems of university teachers' information technology teaching ability improve [M]. Beijing: science press, 2012.9.

[5] Wen-lan Zhang compiled. Information technology and curriculum integration. Shaanxi, shanxi normal university publishing co., LTD., 2012.07.

[6] Feng-mei Yang, Jing-sheng Zhang. Modern education technology. Beijing: higher education press, 2013.04.

[7] Wang Jason kidd editor. The modern education technology. Higher education press, 2011.09. 
[8] Normal education department of ministry of education, teaching staff education technology ability standard, normal university, Beijing normal university, 2005.8

[9] Xin-min sang editor, learning science and technology: information age college students learning ability training, higher education press, 2009.9
[10] Li Shuming, James tien, such as editor, Multimedia Technology and Education, Teacher Education Series Textbooks) Tsinghua university press, 2010.6 